\title{
Determinants of Local People's Perception on the Trade-Off between Conservation and Poverty Reduction in Community based Natural Resource Management: A Case Study of Tonle Sap Lake, Cambodia
}

\author{
Vong Rylida1)*
}

\author{
地域社会型資源管理における環境保全と貧困削減の間での \\ トレードオフ関係の住民認識を規定する要因 \\ 一カンボジアのトンレンサップ湖の事例— \\ ヴォンリーリダー 1$) *$
}

カンボジアのトンレンサップ湖では, 漁業振興策 として, 環境保全と貧困削減を目的とする地域社会 型資源管理が実施されている. この 2 つの目的の達 成について，相異なるトレードオフの関係（win-win, win-lose, lose-lose）が住民の中で認識され, 資源管 理の持続性が危ぶまれている. 本研究の目的は, 住民 認識に基づき，8つの共用資源管理原則及び個人属
性の視座から，トレードオフの関係の認識に拉ける 差異を規定する要因を明らかにすることである。一 つの地域社会型資源管理を事例に取り，無作為抽出 した 188 世帯から収集したデータを使って順序ロジ スティック回帰分析した結果, 排除・モニタリン グ・組織といら共用資源管理原則に関する認識が統 計的に有意な規定要因として同定された.

Key Words: Determinants, Trade-Off, Community-Based Natural Resource Management, Tonle Sap Lake

\section{Introduction}

Community based natural resource management (CBNRM) has become a popular approach in natural resource management. In theory, CBNRM can achieve two objectives simultaneously: conservation and poverty reduction. However, some scholars believe that in the real world achieving both objectives simultaneously is rhetoric (Redford et al., 2006). It is the time that we should face the fact that there is normally trade-off between these two objectives (Brown, 2004). Whether CBNRM can achieve those objectives simultaneously has become one of the most recent debates among scholars and practitioners (Holland, 2012).
The core meaning of the word "trade-off" is acknowledging that to gain something, it is unavoidable to give up something else, which is incurred by various choices and actions in domains of conservation and poverty reduction (Brown, 2004). Trade-off between conservation and poverty reduction is divided into four levels: (1) win (conservation)-win (poverty reduction), (2) win (conservation)-lose (poverty reduction), (3) lose (conservation)-win (poverty reduction), and (4) lose (conservation)-lose (poverty reduction) (Sunderlin et al., 2005).

Ostrom (1990) proposed eight principles to make resource management regime including CBNRM successful. Those principles include exclusion (well-

\footnotetext{
1) Graduate School of International Development, Nagoya University; 名古屋大学大学院国際開発研究科

*E-mail: vongrylida@gmail.com

(The Association for Regional Agricultural and Forestry Economics
} 
defined boundaries), appropriated rules, collectivechoice arrangements, monitoring, graduated sanctions, conflict-resolution mechanisms, minimum recognition of rights by external government officials, and nested enterprises. These principles were used explicitly or implicitly to explain the success of a specific resource management regime by some researchers like Pagdee et al. (2006). Those principles were used to assess the success of either conservation or poverty reduction, but not trade-off between two of them. Those eight principles were proposed by Ostrom (1990) for successful resource management, but success only in one objective cannot really determine the success of resource management. For example, although fishery resource conditions may have improved, fulfillment of local people's needs may not have improved significantly because of restrictive regulations that have been established to improve the fishery resource conditions. Therefore, it seems that using those principles to assess only one side of success is not enough to prove if the resource management regime is really successful.

Moreover, most of those previous studies focused only on a macro level like regional or country level by using the secondary data. It is true that we can make a generalization from those studies. However, their results were likely to be from perception of the researchers rather than that of the local people, which did not really represent what the local people perceived. The local people's perception is very important for success of a project or policy since it can affect their participation and support for it (Allendorf et al., 2012). Hence, judging one factor as a determinant for successful resource management should be from the local people's perception rather than that of the researchers.

To fulfill the aforementioned shortcomings of the previous studies, this study aims to identify the determinants of trade-off between conservation and poverty reduction in CBNRM by using the local people's perception. On one hand, the Ostrom's principles are considered as a comprehensive guideline for successful resource management. On the other hand, there is a debate that some of those principles are not applicable in the real world (Cleaver, 1999) and are not supported by empirical literature as found by Cox et al. (2010). Therefore, to contribute more to the ongoing debate, this study used the Ostrom's principles as the determinants of trade-off between conservation and poverty reduction from the local people's perception. A CBNRM-implemented community called Chivieng, located in a Tonle Sap Lake (TSL) area was used as a case study.

\section{Management in Tonle Sap Lake, Cambodia}

Most parts of the TSL areas used to be managed under the commercial fishing lot system for more than 100 years by businessmen. During that time, the small-scale fishermen had limited fishing grounds for fishing. However, around $56 \%$ of the fishing grounds managed under the commercial lot system were reduced and granted to the local people in the first fishery policy reform in 2006, and in the second fishery policy reforms in 2012 the commercial lot system was totally abolished from the TSL areas (Jones and Sok, 2015). Currently, the TSL areas are under management of both the government and local communities that are implementing CBNRM.

CBNRM was first implemented in the TSL areas in 2006 to manage the new released fishing grounds from the commercial lot system. It aims to conserve the fishery resources and reduce poverty of the local people particularly small-scale fishermen. There were 213 CBNRM-implemented communities in the TSL areas in 2013 (Jones and Sok, 2015). The CBNRMimplemented communities in the TSL areas have followed from the first until the seventh principles suggested by Ostrom (1990) except for the eighth principle. The nested enterprises, which refers to a vertical linkage between the local people and government as suggested by Ostrom (1990), refers to a horizontal linkage between the government officials themselves in this study context. Those government officials are from different institutions including 
Fishery Administration under Ministry of Agriculture, Forestry, and Fisheries, Tonle Sap Basin Authority under Ministry of Water Resources and Meteorology, and Ministry of Environment (Jones and Sok, 2015). It is criticized that their duty and responsibilities overlap with one another and are not clear, giving a chance for some of the government officials to seek rent from the fishermen. The fishermen accuse some of them of negligence in their work, causing more illegal fishing activities in the TSL areas (Thol and Sato, 2014).

Not all the communities in the TSL areas are implementing CBNRM. Those non-CBNRM implemented communities have not adopted most of the Ostrom's principles. Normally, the resource management in those communities is fully managed by the government officials.

\section{Methodology}

\section{(1) Study area}

This study was conducted in one of CBNRMimplemented communities in the TSL areas called Chivieng, located in Kors Chivieng commune, Eak Phnom district, Battambang province. Chivieng covered three villages namely Preak Toal, Kompong Prohok, and Ornlong Taour. As of 2014, its total population was 1,448 households. Around $90 \%$ of the local people were fishermen, and the rest engaged in fish trading, aquaculture, and working in the ecotourism-related jobs like providing accommodation to tourists and being a tour guide. As of $2014,86 \%$ of the local people lived on less than US $\$ 1.25$ per day, which was below the poverty line.

Chivieng was selected as a sample CBNRM because it was one of the oldest CBNRM-implemented communities in the TSL areas. It has implemented CBNRM since 2006, which was the beginning year of CBNRM implementation in the TSL areas. Besides its long duration of CBNRM implementation, Chivieng was considered the most active CBNRM-implemented community in terms of fishery resource conservation and poverty reduction.

In terms of fishery resource conservation, the patrollers, who were the local people, in Chivieng regularly patrolled its fishing grounds and protected areas. The CBNRM committee also raised awareness of fishery resource conservation for the local people. Regarding poverty reduction, the CBNRM committee cooperated with an NGO called Osmose whose job was related to ecotourism to distribute financial benefits to the local people by providing jobs for them.

\section{(2) Data collection}

Structured interview, key informant interview, and focus group discussion (FGD) were used to collect the data. Only active members of CBNRM ${ }^{1}$ were selected for the structured interview. The reason is based on the fact that those who participated actively in CBNRM-related activities like patrolling and meeting were more likely to observe and know the impact of CBNRM implementation; therefore, their perception would be more accurate than that of non- or passive members. Among 1,448 households, 1,115 households were CBNRM members. The name list and reports of the participants in each CBNRM related activity were used to know who were CBNRM members and number of times that they participated in the activities, respectively. Their activeness was judged by the number of times they participated in those activities in 2014, which was one year before the time of interview. Those who participated in five times or around $80 \%$ of the CBNRM related activities were considered the active members for this study.

Convenient sampling was made to collect the samples due to time constrain and availability of those active CBNRM members. Initially, the overall sample size was 223; however, because some of the interviewed households' answers were not consistent, the total sample size was 188 .

To understand the general situations of the study area, the key informants interview with the members of the CBNRM committee, village and commune chiefs, the local government officials and FGD with the local people were conducted.

The dependent variable was the perception of the local people on trade-off between conservation and 
poverty reduction. In this study, the levels of trade-off were divided only into three levels because there were a few samples for win-lose and lose-win levels. These two levels were combined into one level of trade-off namely win-lose and vice versa. Therefore, trade-off perception in this study were (1) lose-lose, (2) winlose and vice versa, and (3) win-win. Lose-lose means the respondent thought that CBNRM did not achieve both conservation and poverty reduction. Win-lose and vice versa means the respondent thought CBNRM achieved either conservation or poverty reduction. Win-win means the respondent thought CBNRM achieved both conservation and poverty reduction.

Table 1 shows the detail of those questions and their measurements and answers.

There were two steps to determine the level of trade-off perception of each respondent. The first step (from questions 1 to 8 ) was to initially know the respondent's perception in each aspect, conservation and poverty reduction. The second step (from question 9 to 12) was to check the consistency of the answers from the previous questions and determine the level of trade-off perception. If the respondent's answer to question 9 was Yes, and his or her answers to question 1, 3, 5 and 7 were also Yes, it could be assumed that there was a consistency with his or her answers and the level of trade-off perception was win-win. If the respondent's answer was No to either conservation or poverty reduction, and the answer for question 9 was No, it could be assumed that there was a consistency with his or her answer. The respondent had to answer question 11. If his or her answer was Yes to either the first or second answer option, the level of trade-off perception was win-lose and vice versa. If the answer was Yes to the third answer option, the level of tradeoff perception was lose-lose. If the respondent's

Table 1. Questions and measurements for the dependent variable

\begin{tabular}{|c|c|c|}
\hline Aims & Questions & $\begin{array}{l}\text { Measurements and answers in } \\
\text { percentage in parenthesis }\end{array}$ \\
\hline \multirow[t]{4}{*}{ Conservation } & $\begin{array}{l}\text { 1. Do you think those protected areas are efficient to conserve the } \\
\text { fishery resources? }\end{array}$ & $\begin{array}{l}\mathrm{No}=0(40 \%) \\
\mathrm{Yes}=1(60 \%)\end{array}$ \\
\hline & 2. Why do you think so? ${ }^{1)}$ & \\
\hline & $\begin{array}{l}\text { 3. Do you think the patrolling activities conducted by the local patrollers } \\
\text { are useful to reduce the illegal fishing activities? }\end{array}$ & $\begin{array}{l}\text { No }=0(39.2 \%) \\
\mathrm{Yes}=1(60.8 \%)\end{array}$ \\
\hline & 4. Why do you think so? & \\
\hline \multirow[t]{4}{*}{ Poverty reduction } & 5. Have your livelihoods improved after CBNRM implementation? & $\begin{array}{l}\text { No }=0(30.2 \%) \\
\text { Yes }=1(69.8 \%)\end{array}$ \\
\hline & 6. Why do you think so? & \\
\hline & $\begin{array}{l}\text { 7. Do you think the protected areas established by CBNRM committee } \\
\text { have affected your livelihoods or fishing activities? }\end{array}$ & $\begin{array}{l}\mathrm{No}=0(40 \%) \\
\mathrm{Yes}=1(60 \%)\end{array}$ \\
\hline & 8. Why do you think so? & \\
\hline \multirow[t]{7}{*}{$\begin{array}{l}\text { Consistency check \& } \\
\text { level of trade-off }\end{array}$} & $\begin{array}{l}\text { 9. Do you think CBNRM has improved both your livelihoods and fishery } \\
\text { resource conservation? }\end{array}$ & $\begin{array}{l}\text { No }=0(50 \%) \\
\text { Yes }=1(50 \%)\end{array}$ \\
\hline & 10. Why do you think so? & \\
\hline & (If the answer for Question 9 is No) & \\
\hline & 11. Between livelihoods and conservation, which one do you think & 1. Livelihood only (19.8\%) \\
\hline & CBNRM has helped to improve? & 2. Conservation only (10\%) \\
\hline & & $\begin{array}{l}\text { 3. Neither livelihood nor } \\
\text { conservation }(20.2 \%)\end{array}$ \\
\hline & 12. Why do you think so? & \\
\hline
\end{tabular}

Source: Author's interview survey in 2016.

1) The Why question was asked to know the reason(s) making the respondent answer the previous question. 
answer was not consistent, the information from that respondent was dismissed.

Table 2 describes the independent variables in detail and their measurements and answer.

There were two groups of independent variables in this study: household socioeconomic characteristics and perceptions of the CBNRM members on the Ostrom's principles. Although this study aims to examine the determinants from the Ostrom's principles, some studies like Fiallo and Jacobson (1995) suggested that some socioeconomic characteristics like age, education level, and occupation can affect the perception of the local people on a resource management regime. Besides, the experience that a respondent has in the previous management, the commercial lot system in this study, may affect the respondent's perception. According to Shackleton et al. (2002), the local people's perception is strongly shaped by a historical context of the previous management in terms of the degree of access to the resources. The local people will have positive perception to the new resource management regime when it allows them to have more access to the resources than the previous one did. Hence, those socioeconomic characteristics were also collected and included in the model to investigate and control their effects on the local people's perception on trade-off.

\section{(3) Ordered logit model}

Ordered logit model (OLM) was used to determine which independent variable(s) significantly affects the dependent variable that was measured in terms of three ordinal scales, three levels of trade-off perception between conservation and poverty reduction. Stata 13 was used to run the model.

The empirical model used in this study is expressed as follows:

Table 2. Definitions and measurements of some of the independent variables

\begin{tabular}{|c|c|c|}
\hline Variables & Definitions & $\begin{array}{l}\text { Measurements and answers in } \\
\text { percentage in parenthesis }\end{array}$ \\
\hline $\begin{array}{l}\text { Experience with the } \\
\text { previous management } \\
(\mathrm{Exp})^{1)}\end{array}$ & $\begin{array}{l}\text { If the respondent has had positive experiences with the previous } \\
\text { management before CBNRM implementation }\end{array}$ & $\begin{array}{l}\text { No=0 }(81.38 \%) \\
\text { Yes }=1(18.62 \%)\end{array}$ \\
\hline Exclusion (Exc) & $\begin{array}{l}\text { If the respondent thinks that he has clearly defined rights to fish or } \\
\text { harvest resources }\end{array}$ & $\begin{array}{l}\mathrm{No}=0(20.2 \%) \\
\mathrm{Yes}=1(79.8 \%)\end{array}$ \\
\hline Appropriate rules (Rul) & $\begin{array}{l}\text { If the respondent thinks the fishing rules and regulations are suitable } \\
\text { for resource conditions }\end{array}$ & $\begin{array}{l}\text { No }=0(2.6 \%) \\
\text { Yes }=1(97.4 \%)\end{array}$ \\
\hline $\begin{array}{l}\text { Collective choice } \\
\text { arrangement (Col) }\end{array}$ & $\begin{array}{l}\text { If the respondent could modify any fishing rule or regulation during } \\
\text { previous CBNRM meetings }\end{array}$ & $\begin{array}{l}\text { No }=0(60.6 \%) \\
\text { Yes }=1(39.4 \%)\end{array}$ \\
\hline Monitors (Mon) & $\begin{array}{l}\text { If the respondent thinks the patrollers or monitors are responsible } \\
\text { for their work in terms of combatting illegal fishing activities }\end{array}$ & $\begin{array}{l}\text { No }=0,(14.9 \%) \\
\text { Yes }=1(85.1 \%)\end{array}$ \\
\hline Graduated sanctions (San) & $\begin{array}{l}\text { If the respondent thinks that illegal fishermen have been punished } \\
\text { according to seriousness of violations }\end{array}$ & $\begin{array}{l}\mathrm{No}=0(70.2 \%) \\
\mathrm{Yes}=1(29.8 \%)\end{array}$ \\
\hline $\begin{array}{l}\text { Conflict-resolution } \\
\text { mechanisms (Con) }\end{array}$ & $\begin{array}{l}\text { If there is a low cost conflict resolution mechanism for conflicts } \\
\text { related to fishing activities }\end{array}$ & $\begin{array}{l}\mathrm{No}=0(5.8 \%) \\
\mathrm{Yes}=1(94.2 \%)\end{array}$ \\
\hline $\begin{array}{l}\text { Minimum rights' } \\
\text { recognition from the } \\
\text { external government } \\
\text { officials ( } R e c)\end{array}$ & $\begin{array}{l}\text { If the respondent thinks the government effectively support their } \\
\text { community in conservation and livelihood improvement }\end{array}$ & $\begin{array}{l}\text { No }=0(38.3 \%) \\
\mathrm{Yes}=1(61.7 \%)\end{array}$ \\
\hline Nested enterprises (Nes) & $\begin{array}{l}\text { If the respondent thinks that there are different stakeholders } \\
\text { involving in conservation and livelihood improvement in their } \\
\text { community }\end{array}$ & $\begin{array}{l}\text { No }=0(56.4 \%) \\
\mathrm{Yes}=1(43.6 \%)\end{array}$ \\
\hline
\end{tabular}

Source: Author's interview survey in 2016.

1) The variables on community and resource boundaries were excluded from the analysis as $99 \%$ of the respondents said that their community had clearly defined boundaries for both. 


$$
z_{i}=\alpha+\beta_{1} x_{1}+\beta_{2} x_{2}+\varepsilon_{i}
$$

where $z_{\mathrm{i}}$ is the dependent variable representing the level of trade-off perception in CBNRM. The dependent variable in this study (1) lose-lose, (2) winlose and vice versa, and (3) win-win. $\mathrm{x}_{1}$ is household socioeconomic characteristics, and $\mathrm{x}_{2}$ is the perception of household on each of the Ostrom's principles. Gender variable was not included in the model because there were only 10 females out of 188 respondents, and it did not make many differences to the model when included. According to the previous studies like Fiallo and Jacobson (1995), gender was not included. Additionally, in this study's context, it is highly likely that gender has no impact on the perception of CBNRM. $\beta$ is the coefficient of the regression, interpreted as log-odds, and $\varepsilon_{\mathrm{i}}$ is an error term.

OLM assumes that the distance between each category of the outcome is proportional. Brant test and likelihood ratio test (LRT) are used to test this assumption (Long and Cheng, 2004).

\section{Results and Discussion (1) Results}

Table 3 shows the empirical results from OLM.

Brant test and LRT show that the assumption is not violated. Therefore, the results from OLM are validated.

According to Table 3, three out of the eight principles proposed were significant determinants of trade-off perception. The first two significant principles, exclusion and monitoring, were positive determinants; but the last significant one, nested enterprises, was a negative determinant.

\section{(2) Discussion}

From the OLM analysis, exclusion was significantly a positive determinant for trade-off perception in CBNRM. Although this finding was similar to that of the previous studies like Ostrom (1990) and Pinkerton and Weinstein (1995), the explanation for this finding is quite different from their explanations. According to
Table 3. Determinants of trade-off perception

\begin{tabular}{lll}
\hline $\begin{array}{ll}\text { No. of observation }=188 \\
\text { Prob }>\text { chi2 }=0.0000\end{array}$ & LR chi2 $(12)=47.69$ & \\
\hline Trade-off perception & & \\
\hline Inde.var. & Coef. & Std.Err. \\
Age & 0.2 & 0.3 \\
Edu & 0.39 & 0.27 \\
Ocu & 0.3 & 0.11 \\
Exp & 0.07 & 0.39 \\
Exc & $1.51^{* * *}$ & 0.41 \\
Rul & 0.52 & 0.92 \\
Col & 0.2 & 0.36 \\
Mon & $1.39^{* * *}$ & 0.4 \\
San & 0.09 & 0.61 \\
Con & 0.31 & 0.56 \\
Rec & 0.04 & 0.62 \\
Nes & $-0.63^{*}$ & 0.37 \\
Cut1 & 2.86 & 0.61 \\
Cut2 & 1.14 & 0.57 \\
\hline Brant test: Chi2 (12): 18.15 & P $>$ chi2: 0.11 & \\
LRT: Chi2 (12): 19.56 & Pro $>$ chi2: 0.17 & \\
\hline & & \\
\hline
\end{tabular}

the study context, it was true that Chivieng had its clearly defined boundaries for their own community and resources. However, in reality, both the local and outside fishermen did not pay attention to the boundaries since they thought that fish could move everywhere, and it was unpractical for them to fish only in a specific fishing ground. Therefore, a likely explanation for this finding is that the clearly defined rights to withdraw the resources for them referred to fairness that everyone could go fishing in different fishing grounds disregarding the boundaries. The similar scenario was also mentioned in other studies arguing that the participants could have ad hoc negotiation with one another to access the resources (Cleaver, 1999).

Another significantly positive determinant for tradeoff perception in CBNRM was monitoring. This finding mirrored that of Ostrom (1990). The patrollers were the local people and were active in the patrolling activities in the study area, it was no doubt that this variable was a positive determinant. Although in the context of the study area, those patrollers had no right 
to arrest or punish the illegal fishermen, according to most of the respondents, around $85 \%$, the patrolling activities by their monitors could at least reduce some of the illegal fishing activities, which was much more effective than the government officials.

Nested enterprises variable is in tension with most of the previous studies' findings due to its negative sign. Nested enterprises variable in the context of this study did not refer to a vertical linkage between the local people and government officials as referred by Ostrom (1990), but it rather referred to the horizontal linkage between the government officials themselves. According to FGD, many fishermen complained that there were too many government officials working in their community, and some of them often sought rent from the fishermen. The complain is similar to the claim of Thol and Sato (2014). Therefore, it is no doubt that nested enterprises variable was perceived by the local people as a negative determinant.

\section{Conclusion}

To sum up, this study found that most of the principles suggested by Ostrom (1990) were positive determinants of the trade-off perception in CBNRM except for the nested enterprises principle. The negative finding of this principle suggests that the number of different stakeholders in resource management is not enough to manage the resource successfully. How effective their roles are in resource management should be more concerned. To some extent, there should be a clear cut for their duty and responsibilities to ensure effectiveness in resource management.

The Ostrom's principles are important to follow to conserve the resources and reduce poverty successfully. However, more modification of the existing principles is needed to make those principles both important and sufficient.

\section{Notes}

1 CBNRM members are those having registered their names with the CBNRM committee and fulfill the requirements to be the members like paying annual membership fee.

\section{References}

Allendorf, T. D., Aung, M. and Songer, M. (2012) Using residents' perceptions to improve park-people relationships in Chatthin wildlife sanctuary, Myanmar. Journal of Environmental Management, 99, 36-43.

Brown, K. (2004) Trade-off analysis for integrated conservation and development. In: T. O. McShane and M. P. Well (Eds.) Getting Biodiversity Projects to Work: Towards More Effective Conservation and Development. New York: Columbia University Press, 232-255.

Cleaver, F. (1999) Paradoxes of participation: Questioning participatory approaches to development. Journal of International Development, 11(4), 597-612.

Cox, M., Arnold, Q. and Tomas, S. V. (2010) A review of design principles for community-based natural resource management. Ecology and Society, 15(4). (https:// www.ecologyandsociety.org/vol15/iss4/art38/) [Accessed July 17, 2015].

Fiallo, E. A. and Jacobson, S. K. (1995) Local communities and protected areas: Attitudes of rural residents towards conservation and Machalilla National Park, Ecuador. Environmental Conservation, 22(3), 241-249.

Holland, M. B. (2012) The role of protected areas for conserving biodiversity and reducing poverty. In: J. C. Ingram, F. DeClerck and C. R. del Rio (Eds.) Integrating Ecology and Poverty Reduction: The Application of Ecology in Development Solutions. London: Springer, 253-272.

Jones, R. W. and Sok, S. (2015) Impacts and implications of deep fisheries reforms on the governability of small-scale fisheries in Tonle Sap Lake, Cambodia. In: S. Jentoft and R. Chuenpagdee (Eds.) Interactive Governance for Small-Scale Fisheries. Cham: Springer International Publishing, 539-557.

Long, J. and Cheng, S. (2004) Regression models for categorical outcomes. In: M. Hardy and A. Bryman (Eds.) Handbook of Data Analysis. London: SAGE Publications Ltd, 259-284.

Ostrom, E. (1990) Governing the Commons. Cambridge: Cambridge University Press.

Pagdee, A., Kim, Y. and Daugherty, P. J. (2006) What makes community forest management successful: A meta-study from community forests throughout the world. Society \& Natural Resources, 19(1), 33-52.

Pinkerton, E. and Weinstein, M. (1995) Fisheries That Work: Sustainability through Community-Based Management. Vancouver: David Suzuki Foundation.

Redford, K. H., Robinson, J. G. and Adams, W. M. (2006) Parks as shibboleths. Conservation Biology, 20(1), 1-2.

Shackleton, S., Campbell, B. M., Wollenberg, E. and Edmunds, D. 
(2002) Devolution and community-based natural resource management: Creating space for local people to participate and benefit? Natural Resources Perspectives, 76, 1-6.

Sunderlin, W. D., Angelsen, A., Belcher, B., Burgers, P., Nasi, R.,

Santoso, L. and Wunder, S. (2005) Livelihoods, forests, and conservation in developing countries: An overview. World Development, 33(9), 1383-1402.

Thol, D. and Sato, J. (2014) Is greater fishery access better for the poor? Explaining de-territorialisation of the Tonle Sap, Cambodia. Journal of Development Studies, 50(7), 962-976. 